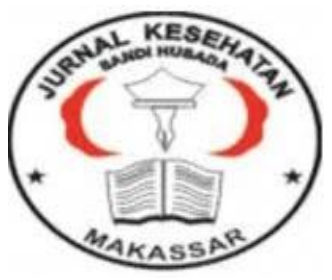

Jurnal Ilmiah Kesehatan Sandi Husada

hhttps://akper-sandikarsa.e-journal.id/JIKSH

Volume 9, Nomor 2, Desember 2020, pp 792-797

p-ISSN: 2354-6093 dan e-ISSN: 2654-4563

DOI: $10.35816 /$ jiskh.v10i2.403

\title{
Pengaruh Pola Asuh Terhadap Status Gizi Anak
}

Influence of Foster Pattern About the Status of Child Nutrition

Hasrul $^{1}$, Hamzah ${ }^{2}$, Aslinda Hafid ${ }^{3}$

1,2 Keperawatan STIKES Muhammadiyah Sidrap

3Kebidanan Puskesmas Lawawoi

Artikel info

Artikel history:

Received; Juli 2020

Revised: Agustus 2020

Accepted; Agustus 2020

\begin{abstract}
Abstrak
Latar Belakang Status gizi adalah ekspresi dari keadaan keseimbangan dalam bentuk variabel tertentu atau perwujudan nutriture dalam bentuk variabel tertentu, status gizi optimal adalah keseimbangan antara asupan dan kebutuhan zat gizi. Metode; penelitian yang digunakan adalah deskriptif analitik menggunakan pendekatan analisis regresi berganda, dengan jumlah sampel 30 responden. Hasil; tidak ada pengaruh yang signifikan antara pola asuh orang tuaterhadap status gizi anak sekolah dasar didapatkan nilai 0. 551>0,05. Kesimpulan; bahwa tidak ada pengaruhnya pola asuh orang tua terhadap status gizi anak sekolah dasar. Dalam pengembangan informasi yang mempunyai kontribusi terhadap ilmu pengetahuan khususnya dalam pendidikan keperawatan tentang status gizi pada anak.
\end{abstract}

\begin{abstract}
The background of nutritional status is the expression of a state of balance in the form of a certain variable or manifestation of nutriture in the form of certain variables, optimal nutritional status is the balance between intake and need for nutrients. Method; The research used is descriptive analytic using multiple regression analysis approach, with a sample size of 30 respondents. Result; There is no significant effect between parenting styles of parents on the nutritional status of elementary school children, the value is 0. 551> 0.05. Conclusion; that there is no effect of parenting style on the nutritional status of elementary school children. In developing information that has a contribution to science, especially in nursing education about the nutritional status of children.
\end{abstract}




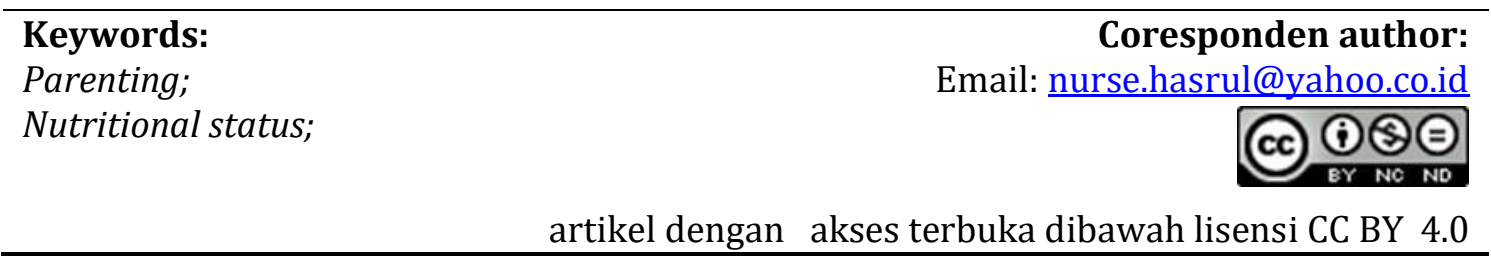

\section{Pendahuluan}

Status gizi merupakan keadaan tubuh sebagai akibat dari konsumsi makanan dan penggunaan zat-zat gizi. Almaizer, 2006 dalam (Dian, dkk, 2015). Status gizi adalah ekspresi dari keadaan keseimbangan dalam bentuk variabel tertentu atau perwujudan nutriture dalam bentuk variabel tertentu, status gizi optimal adalah keseimbangan antara asupan dan kebutuhan zat gizi (Merryana Adriani, 2016). Masalah gizi pada anak sekolah dasar saat ini masih cukup tinggi. Kehidupan manusia, dimana setiap insan yang berumur pasti akan melewati fase ini. Semakin bertambahnya usia maka seluruh fungsi organ telah mencapai puncak maksimal sehingga yang terjadi sekarang adalah penurunan fungsi organ (Hamsah, 2020).

Berdasarkan hasil Riset Kesehatan Dasar (Kemenkes, 2018) didapatkan status gizi anak 512 tahun menurut indeks massa tubuh/umur di Indonesia, yaitu prevalensi kurus adalah 9,3, terdiri dari 2,5\% sangat kurus dan 6,8\% kurus. Masalah gemuk pada anak di Indonesia juga masih tinggi dengan prevalensi $20,6 \%$ terdiri dari gemuk $11,1 \%$ dan sangat gemuk (obesitas) 9,5\%. Sedangkan prevalensi pendek yaitu 23,6\% terdiri dari 6,7 sangat pendek dan 16,9\% pendek (Riskesdas, 2018). Anak usia sekolah adalah masa remaja awal anak dalam rentang usia 6 sampai 12 tahun yang memasuki masa pubertas. Anak usia sekolah pada umumnya mempunyai kondisi gizi yang lebih baik daripada kelompok balita. Meskipun demikian, masih terdapat berbagai kondisi gizi anak sekolah yang tidak baik. Hal ini dapat disebabkan oleh kondisi yang berasal dari dalam diri individu, antara lain usia, jenis kelamin, dan penyakit infeksi (Mas'ud, dkk, 2015).

Anak usia sekolah membutuhkan asupan gizi lebih banyak yang sangat dibutuhkan untuk tumbuh kembang menuju remaja. Anak laki-laki lebih banyak membutuhkan zat gizi sumber energi dibandingkan dengan anak perempuan karena anak laki-laki cenderung memiliki banyak aktifitas, namun jika tidak diimbangi dengan konsumsi makanan yang dapat menyebabkan masalah gizi. Konsumsi makanan yang baik namun keadaan anak sakit atau mengalami penyakit infeksi dapat menyebabkan anak mengalami status gizi yang tidak baik pula (Oktafiana, 2016). Anak Sekolah Dasar (SD) adalah anak usia 6-12 tahun. Pertumbuhan dan perkembangan anak sangat membutuhkan gizi yang cukup agartidak terjadi penyimpangan pada pertumbuhan dan perkembangan anak. Gizi yang kurang juga akan membuat sistem imun pada anaklemah. Aktifitas yang cukup tinggi dan kebiasaan makan yang tidak teratur pada anak sering mengakibatkan ketidakseimbangan antara asupan dan kecukupan gizi. Ketidakseimbangan antara asupan dan kecukupan gizi akan menimbulkan masalah gizi, baik itu masalah gizi lebih maupun gizi kurang (Seprianty, dkk, 2015).

(Sambo, dkk, 2020) berpendapat bahwa salah satu masalah kesehatan yang terdapat di Indonesia saat ini adalah gizi kurang. Faktor yang dapat berpengaruh terhadap gizi seseorang adalah pola makan. Pola makan sangat erat kaitannya dengan macam, jumlah dan komposisi makanan yang dikonsumsi setiap hari. Pemenuhan makanan yang baik bagi anak akan mempengaruhi status gizi pada anak. Bahwa ada hubungan pola makan dengan status gizi pada anak usia prasekolah di TK Kristen Tunas Rama. Berdasarkan penelitian ini diharapkan agar ibu lebih memperhatikan status gizi anaknya yaitu dengan memberikan makanan yang mengandung gizi baik pada anak. Bahwa terdapat hubungan 
antara status gizi dan kelelahan pada produktivitas tenaga kerja. Oleh karena itu pengaturan status gizi yang optimal dengan minimalisasi kelelahan kerja diperlukan agar tercapai produktivitas yang optimal. Pengaturan jam kerja, penyelenggaraan makan, ktersediaan air minum dan sarana olahraga dapat menjadi opsi untuk memantau status gizi pekerja dan menghindari kelelahan sebagai faktor yang berpengaruh terhadap produktivitas (Ramadhanti, 2020).

Berdasarkan data Dinas Kesehatan Kabupaten Sidenreng Rappang tahun 2020, hasil prevalensi kurus dan berat badan anak umur 6-14 tahun, laki-laki tergolong kurus sebanyak 11,6\%, berat badan lebih sebanyak 1,3\% dan perempuan tergolong kurus sebanyak 14,7\% dan berat badan lebih sebanyak 1,1\%, hasil data puskesmas Pangkajene Kabupaten Sidenreng Rappang terdapat prevalensi status gizi anak 17,7\%, kurus dengan prevalensi 7,91\% dan 4,5\% kurus sekali. Fokus penelitian ini adalah untuk melihat apakah pola asuh yang diterapkan orangtua pada anak khususnya anak usia sekolah dasar dapat mempengaruhi status gizi anaknya.

\section{Metode}

Metode peneitian yang digunakan adalah metode deskriptif analitik dengan pendekatan Analisis Regresi Berganda. Populasi dalam penelitian ini adalah seluruh siswa SD Negeri yang berdomisili diwilayah kerja puskesmas pangkajene. Teknik pengambilan sampel yaitu purposive sampling dengan jumlah sampel pada penelitian ini sebanyak 30 sampel. Analisis statistik yang digunakan adalah analisis univariat dan analisis bivariat. Analisis univariat (Kelas, jenis kelamin, berat badan, tinggi badan, pola asuh dan status gizi). Instrumen yang digunakan pada penelitian ini adalah Kuesiner yang sudah dilakukan uji validitas dan uji reabilitas menggunakan program SPSS.

\section{Hasil Dan Pembahasan}

Tabel.1 Analisis Univariat

\begin{tabular}{|c|c|c|}
\hline Kelas & Frekuensi & $(\%)$ \\
\hline $1 \mathrm{~A}$ & 18 & 60,0 \\
\hline $1 \mathrm{~B}$ & 12 & 40,0 \\
\hline Total & 30 & 100 \\
\hline \multicolumn{3}{|l|}{ Jenis Kelamin } \\
\hline Laki- laki & 20 & 66,7 \\
\hline Perempuan & 10 & 33,3 \\
\hline Total & 30 & 100 \\
\hline \multicolumn{3}{|l|}{ Berat Badan } \\
\hline 13- 16 & 8 & 26,6 \\
\hline $17-20$ & 11 & 36,6 \\
\hline $21-24$ & 6 & 20,0 \\
\hline $25-36$ & 5 & 16,6 \\
\hline Total & 30 & $100 \%$ \\
\hline \multicolumn{3}{|l|}{ Tinggi Badan } \\
\hline $106-114$ & 5 & 16,7 \\
\hline $115-118$ & 10 & 33,3 \\
\hline $119-122$ & 6 & 20,0 \\
\hline $123-127$ & 9 & 30,0 \\
\hline Total & 30 & 100 \\
\hline
\end{tabular}




\begin{tabular}{|c|c|c|}
\hline Pola Asuh Baik & 25 & 83,3 \\
\hline $\begin{array}{c}\text { Pola Asuh kurang } \\
\text { Baik }\end{array}$ & 5 & 16,7 \\
\hline Total & 30 & 100 \\
\hline \multicolumn{3}{|l|}{ Status Gizi } \\
\hline Gizi Kurang & 12 & 40,0 \\
\hline Gizi Baik & 17 & 56,7 \\
\hline Gizi Lebih & 1 & 3,3 \\
\hline Total & 30 & 100 \\
\hline
\end{tabular}

Sumber: data primer 2020

Tabel .2 Analisis pengaruh Pola Asuh Orang Tua Terhadap Status Gizi

\begin{tabular}{|c|c|c|c|c|c|}
\hline \multicolumn{6}{|c|}{ Coefficients $^{a}$} \\
\hline \multirow{2}{*}{ Model } & \multicolumn{2}{|c|}{$\begin{array}{l}\text { Unstandardized } \\
\text { Coefficients }\end{array}$} & $\begin{array}{l}\text { Standardized } \\
\text { Coefficients }\end{array}$ & $\mathrm{t}$ & Sig. \\
\hline & $\mathrm{B}$ & $\begin{array}{l}\text { Std. } \\
\text { Error }\end{array}$ & Beta & & \\
\hline (Constant) & 2.517 & .559 & & 4.502 & .000 \\
\hline Asuh Orang Tua & -.539 & .264 & -.368 & -2.041 & .051 \\
\hline
\end{tabular}

Sumber: data primer 2020

Menunjukkan bahwa dari 30 jumlah reponden, reponden yang berkelas 1 A sebanyak 18 orang dengan presentase $(60,0 \%)$ dan responden yang berkelas 1 B sebanyak 12 orang dengan presentase $(40,0 \%)$. Menunjukkan bahwa dari 30 jumlah reponden dalam penelitian ini laki-laki sebanyak 20 orang dengan presentase $(66.7 \%)$ dan perempuan 10 orang dengan presentase (33,3\%).

Menunjukkan bahwa dari 30 jumlah responden, responden dengan berat badan 13-16 sebanyak 8 orang dengan presentase $(26,6)$, responden dengan berat badan 17-20 sebanyak 11 orang dengan presentase $(36,6)$, responden dengan berat badan 21-24 sebanyak 6 orang dengan presentase $(20,0)$ dan responden dengan berat badan 25-36 dengan presentase $(16,6)$.

Menunjukkan bahwa dari 30 jumlah responden, responden dengan tinggi badan 106-114 sebanyak 6 orang dengan presentase $(16,7)$, responden dengan tinggi badan 115-118 sebanyak 10 orang dengan presentase $(33,3)$, responden dengan tinggi badan 119-122 sebanyak 6 orang dengan presentase $(20,0)$ dan responden dengan tinggi badan 123-127 dengan presentase $(30,0)$. Menunjukkan bahwa dari 30 jumlah responden dalam penelitian ini yang memiliki pola asuh orang tua yang baik sebanyak 25 orang dengan presentase $(83,3)$ sedangkan yang memiliki pola asuh yang tidak baik sebanyak 5 orang dengan presentase (16,7). Menunjukkan bahwa dari 30 jumlah responden dalam penelitian ini responden yang mengalami gizi kurang sebanyak 12 orang dengan presentase $(40,0)$, responden yang mangalami gizi baik sebanyak 17 orang dengan presentase $(56,7)$ dan responden yang mengalami gizi lebih sebanyak 1 orang dengan presentase $(3,3)$.

Hasil analsiis diperoleh bahwa nilai t-hitung variabel pola asuh orang tua -2.041 dan nilai sig pola asuh orang tua adalah 0.51. Dengan demikian dibuat persamaan regresi linear dengan mengacu pada rumus $\mathrm{t}$ tabel $=\mathrm{t}(\mathrm{a} / 2 ; \mathrm{n}-\mathrm{k}-1)$. Untuk melakukan Uji $\mathrm{T}$ digunakan tabel coefficients, seperti yang tercantum pada tabel 7. Dari hasil Uji T didapatkan nilai sig 
-2.041 Oleh karena nilai sig 0,51 lebih besar dari 0,05 maka dapat disimpulkan H0 diterima dan Ha ditolak, yang artinya tidak ada pengaruh yang signifikan antara pola asuh orang tua terhadap status gizi. Penelitian ini sejalan dengan yang dilakukan (Suci, 2014) ada beberapa faktor lain yang mempengaruhi status gizi anak salah satunya pengetahuan merupakan hasil tahu dari seseorang setelah melakukan penginderaan terhadap suatu objek. Melalui proses belajar, seseorang akan menjadi tahu sehingga akan dapat merubah perilaku sebelumnya. Sama halnya dengan kurangnya pengetahuan tentang gizi terutama pada sang ibu, akan berdampak pada kurangnya kemampuan mengaplikasikan informasi khususnya tentang gizi yang nantinya akan berakibat pada status gizi anak.

Hal ini sesuai dengan pernyataan (Dardjito, dkk, 2016), pengetahuan gizi orang tua dan status gizi anak berbanding lurus. Semakin baik pengetahuannya semakin baik juga status gizinya. Hal serupa dijabarkan oleh (Makikama, dkk, 2017) pada penelitiannya di SD Negeri Ngesrep 02 Kecamatan Banyumaik Kabupaten Semarang tahun 2014. Pada penelitiannya yang menyatakan bahwa ada hubungan antara pengetahuan orang tua dengan status gizi balita. Pengetahuan akan gizi yang di bawah rata-rata, dapat menyebabkan usaha untuk mengoptimalkan gizi menjadi terhambat. Maka dari itu, pemerintah mengadakan program-program melalui penyuluhan dan lain-lain guna membantu masyarakat dalam mengatasi masalah gizi mereka. Masalah anak pendek (stunting) adalah salah satu permasalahan gizi yang menjadi fokus Pemerintah Indonesia (Rahmadhita, 2020).

Hasil penelitian menunjukkan hamper semua anak mempunyai status gizi baik, anak memiliki lingkar kepala normal, hampir seluruhnya perkembangan anak adalah sesuai, 98,73\% anak memiliki daya lihat normal, anak memiliki daya dengar normal. Hampir seluruhnya anak mempunyai masalah perilaku emosional normal, dan anak tidak mengalami kemungkinan gangguan pemusatan perhatian dan hiperaktifitas (Prastiwi, 2019). Faktor lainnya yang dapat mempengaruhi status gizi adalah pendidikan orang tua. Pendidikan orang tua berkaitan dengan tingkat pengetahuan tentang perawatan kesehatan, kesadaran akan kesehatan anak-anaknya serta gizi untuk anak dan keluarganya. Tingkat pendidikan turut serta mempertimbangkan dalam mudah atau tidaknya seseorang dalam memahami pengetahuan tentang gizi. Seperti yang dijelaskan oleh (Hartono, 2017) semakin tinggi jenjang pendidikan orang tua, semakin orang tua mengerti tentang informasi nutrisi yang harus dipenuhi serta pola makan bagi sang balita. Pendidikan yang tinggi akan memperluas orang tua dalam mendapatkan pengetahuan yang optimal dan dapat berpengaruh dalam hal-hal yang positif (Fitriyani, 2016) mengatakan bahwa pendidikan fomal mempunyai andil yang cukup berpengaruh dalam penerapan gizi di suatu keluarga terutama oleh sang ibu. Ibu yang bertugas menyiapkan dan menyajikan makanan dituntut optimal sehingga dapat memenuhi gizi yang optimal juga pada keluarganya. Sehingga untuk mewujudkan itu semua, diharapkan ibu memiliki kualitas pelayanan yang baik yang mencakup informasi tentang gizi.

Menurut penlitian (Seprianty et al., 2015), menyatakan adanya hubungan antara keadaan ekonomi suatu keluarga dengan status gizi. Masalah kekurangan gizi di Indonesia salah satunya dikarenakan dari kehidupan masyarakat Indonesia yang cenderung masih di bawah standar. Keadaan demikian sangat berpengaruh pada kecukupan gizi dalam suatu keluaga. Keluarga yang masuk dalam kategori miskin, rentan terkena masalah kekurangan gizi. Hal ini dikarenakan karena rendahnya kemampuan untuk memenuhi gizi yang baik. Ada beberapa sindroma kemiskinan yang dapat mempengaruhi status gizi. Yang pertama adalah pendapatan yang tidak menjangkau untuk segala kebutuhan pangan, sandang dan papan. Yang kedua, kualitas dalam mengonsumsi makanan cenderung rendah, tanpa 
memperhatikan nilai gizi di dalamnya. Yang ketiga adalah sanitasi dan akses kesehatan yang buruk

\section{Simpulan Dan Saran}

Hasil penelitian bahwa tidak ada pengaruh yang signifikan antara pola asuh orang tua terhadap status gizi anak sekolah dasar. Saran pada hasil penelitian ini yaitu semoga menjadi literatur dalam pengembangan informasi yang mempunyai kontribusi terhadap pengembangan ilmu pengetahuan khususnya dalam pendidikan keperawatan tentang status gizi pada anak.

\section{Daftar Rujukan}

Amda, K., \& Fitriyani, R. (2016). Membaca ekspresi wajah. Huta Publisher.

Dardjito, E., \& Anandari, D. (2016). Anemia gizi besi pada remaja putri di wilayah Kabupaten Banyumas. Kesmas Indonesia: Jurnal Ilmiah Kesehatan Masyarakat, 8(1), 16-31.

Dian Mustika Nirmala Sari, T. (2015). Pola Asuh Makan Antara Ibu Bekerja Dan Tidak Bekerja Dan Faktor Yang Mempengaruhi Status Gizi Anak Usia Sekolah Dasar (Kasus Di Desa Tingkis, Kecamatan Singgahan, Kabupaten Tuban). Jurnal Tata Boga, 4(1).

Hamsah, I. A. (2020). Gambaran Nutrisi Lansia Di Desa Banua Baru. Jurnal Ilmiah Kesehatan Sandi Husada, 11(1), 1-7.

Hartono, J. (2017). Teori portofolio dan analisis investasi edisi kesebelas. Yogyakarta: BPFE.

Kemenkes, R. I. (2018). Hasil utama RISKESDAS 2018. Online) Http://Www. Depkes. Go. Id/Resources/Download/Info-Terkini/Materi_rakorpop_2018/Hasil\% 20Riskesdas. Retrieved from http://p2ptm.kemkes.go.id/kegiatan-p2ptm/pusat-/harihipertensi-dunia-2019-know-your-number-kendalikan-tekanan-darahmu-dengancerdik

Makikama, C. V, Kawatu, P. A. T., \& Punuh, M. I. (2017). Hubungan Antara Asupan Protein Dengan Status Gizi Pada Anak Kelas 4 Dan 5 Sd Inpres Matungkas Kecamatan Dimembe Kabupaten Minahasa Utara. KESMAS, 6(4).

Mas'ud, H., Rochimiwati, S. N., \& Rowa, S. S. (2015). Studi Evaluasi Sisa Makanan Pasien dan Biaya Makanan Pasien di RSK Dr Tadjuddin Chalid Dan RSUD Kota Makassar. Media Gizi Pangan, 19, 91-95.

Merryana Adriani, S. K. M. (2016). Pengantar gizi masyarakat. Prenada Media.

Oktafiana, R. (2016). Faktor-Faktor Yang Mempengaruhi Status Gizi Anak Usia Sekolah Pada Keluarga Atas Dan Bawah (Kasus Di Desa Sidoharjo, Kabupaten Ponorogo). Jurnal Tata Boga, 5(3).

Prastiwi, M. H. (2019). Pertumbuhan dan Perkembangan Anak Usia 3-6 Tahun. Jurnal Ilmiah Kesehatan Sandi Husada, 10(2), 242-249.

Rahmadhita, K. (2020). Permasalahan Stunting dan Pencegahannya. Jurnal Ilmiah Kesehatan Sandi Husada, 11(1), 225-229.

Ramadhanti, A. A. (2020). Status Gizi dan Kelelahan terhadap Produktivitas Kerja. Jurnal Ilmiah Kesehatan Sandi Husada, 11(1), 213-218.

Sambo, M., Ciuantasari, F., \& Maria, G. (2020). Hubungan Pola Makan Dengan Status Gizi Pada Anak Usia Prasekolah. Jurnal Ilmiah Kesehatan Sandi Husada, 11(1), 423-429.

Seprianty, V., Tjekyan, R. M. S., \& Thaha, M. A. (2015). Status Gizi Anak Kelas III Sekolah Dasar Negeri 1 Sungaililin. Jurnal Kedokteran Dan Kesehatan, 2(1), 181669. 